\title{
Choice of Smallholder Farmers' Adaptation Strategies to Climatic Variability and Their Determinants in Crop Production: The Case of the Central Rift Valley of Ethiopia
}

\author{
Adam Bekele Yitayal Abebe \\ Ethiopian Institute of Agricultural Research, Melkassa Agricultural Research Center \\ Adama, Ethiopia, P. O. Box 436
}

\begin{abstract}
There is a growing focus on the need for proactive management of climate change risk in agriculture and agricultural technologies are deemed necessary for tackling climate adaptation and/or risk management issue in the sector. Thus, this study tries to identify the in-built crop production technology related adaptation and/or risk management strategies with smallholder farmers' perception in moisture-stressed areas of the central rift valley of Ethiopia. Results of descriptive analysis showed that high temperature, short rain and pests (indirectly) have been the most important phenomena of climate change causing loss of crop production, exhaustion and illness. Also, smallholder farmers' adaptation and/or risk management strategies were found to be many and were usually composed of traditional and improved practices. According to farmers, the improved varieties performed from less to higher susceptibility to climate change. Results of the multivariate probit model revealed that farmers' adaptation and/or risk management strategies are governed by different sets of socioeconomic and climatic factors which could be summarized as farmer-specific, technology specific and environment specific. Therefore, it is recommended that policy actions should consider the impact of climate change and the characteristics and diversity of adaptation and/or risk management strategies within the framework of the different socio-economic and local settings influencing farmers' decision.
\end{abstract}

Keywords: Adaptation and/or risk management mechanisms, farmers' decision making behavior

DOI: $10.7176 / \mathrm{JEES} / 9-4-04$

Publication date: April $30^{\text {th }} 2019$

\section{Introduction}

Climate change is one of the most serious environmental challenges facing mankind worldwide. The most adverse effects of climate change are felt mainly by developing countries, especially those in Africa, due to their low level of coping capabilities (Nwafor 2007; Jagtap 2007). Markedly, it affects agriculture, the leading economic sector in these countries, through its direct impact on food production and agricultural productivity (Ziervogel et. al. 2006). Climate change can have severe impact on societies which depend for their existence on traditional agricultural methods (Hassan and Nhemachena, 2008). Ethiopian farmers are no exception.

In Ethiopia, over the past several decades, the temperature increased at about $1.3^{\circ} \mathrm{C}$ per decade (WHO, 2015; McSweeney, C., 2010). The onset and duration of the rainfall seasons, driven mainly by the migration of the Inter-Tropical Convergence Zone, vary considerably inter-annually, causing frequent drought. Harvest failure due to extreme weather events is the most important cause of risk related hardship of Ethiopian rural households, with adverse effects on farm household consumption and welfare (Dercon et. al. 2005).

Planning and implementation of adaptation response strategies and/or risk management practices to the actual or expected climate stimuli is, therefore a strategy that must arise out of necessity by the vulnerable communities. Most agricultural systems have a measure of in-built (autonomous) adaptation and/or risk management capacity but the current trend of climate change could impose new and potentially overwhelming pressures on existing adaptation and/or risk management capacity by weakening the ability of people and ecosystems to cope with, and recover from, extreme climate change events. Accordingly, there is a growing focus on the need for proactive (anticipatory) management of climate change risk (UNDP, 2010). Technology research and development is among the most frequently advocated strategies for tackling climate adaptation and/or risk management issue in agriculture (Crosson, 1983, Rosenberg, 1992). The profound effects of research and technological development on crop and animal productivity in both the developed and developing world are unquestionable (Reilly and Fuglie, 1998).

In order to adapt to climate change, farmers will need access to new and improved technologies, infrastructure, skills/knowledge and financial outlets. The development and effective diffusion of new and improved agricultural practices and technologies will largely shape how and how well farmers adapt to climate change.

Over the past 50 years, more than 1000 crop, livestock and natural resource related technologies have been released and several of them have been disseminated by the Ethiopian Institute of Agricultural Research and other stakeholders of agricultural research and development nationwide among smallholder farmers (MoANR, 
2016). Among these are technologies and practices that are tolerant to drought and increase returns.

However, crop production technologies are changing and very little is known about the roles and distribution of the adopted technologies in fighting against the threats of climate change and in the choice of adaptation and/or risk management strategies among smallholder farmers (Coretha and Edwin, 2015), particularly among those living in moisture-deficit areas of Ethiopia. Past adaptation and/or risk management studies (e.g. Deressa et. al., 2011) the varying perception of farm households in terms of accessing farm resources and adopting specific livelihood strategies; as well as, understanding factors governing 'choices' of available adaptation responses to moisture stress. For instance, some of the farmers prefer less risky technologies (risk averse farmers), while some others are risk takers, who tend to adopt improved technologies, regardless of the potential losses arising from the climate risks; most probably because of the differential local natural resource endowment which can help them to overcome those risks, in case of eventuality. Also, there is a gap in terms of understanding the most important factors governing smallholder farmers' choices of available adaptation and/or risk management mechanisms in areas that are characterized by moisture-stress.

Thus, the coupled understanding of farmers' perception and adaptation response strategies, as related to agricultural technologies and informed decisions by the practitioners and for policy responses to the threats of climate change is becoming critical. This paper tries to explain the scenario of adaptation and/or risk management to climate change via smallholder farmers' choice of strategies in the semi-arid Central Rift Valley of Ethiopia, where scarcity and variability of rainfall coupled with unfavorable temperature is a challenge in crop production.

\section{Methodology}

\subsection{Sampling}

This study was based on surveys conducted in the Central Rift Valley of Ethiopia, particularly in East Shewa and West Arsi zones of Oromia region, where moisture-stress is the major problem. Multistage random sampling was followed to identify 200 sample households for the study. In the first stage, a typical maize-based mixed farming system was identified based on the dominance in land area coverage of crops. Then, three districts; namely, Shalla, Adamitulu and Dugda, were randomly selected from the list of districts in the maize farming system and three "kebeles" were randomly drawn from each district. Finally, sample households were randomly selected following probability proportional to size criteria.

\subsection{Data analysis}

Data was analyzed using descriptive and econometric techniques. The descriptive technique was mainly used to describe socio-economic characteristics of farmers, agricultural technologies and climate change adaptation and/or risk management mechanisms. Multivariate probit model (MVP) was adopted to capture the joint relationships of smallholder farmers' choices of adapting to climate changes. The model was chosen on the ground that, first, farmers' choice of the identified climate change adaptation and/or risk management strategies defined in a dichotomous (yes or no) framework against each strategy; second, such choices could be jointly determined by a set of characteristics that are farm internal and/or farm external and finally, the adaptation and/or risk management strategies may not be mutually exclusive and, as pointed out in Kiefer (1982), ignoring such dependency in multivariate choice models may lead to biased estimates of the choice probabilities and erroneous estimates of the standard errors of the parameters. Moreover, the model, compared to the widely accepted Multinomial Probit model (Alvarez and Nagler, 2000), can help capture correlated responses (Young et. al. 2009) in the event that farmers' decision about one type of strategy is likely to be correlated (jointly determined) with their decision on another type of strategy.

In this study farmers could make distinct or combinations of choices of the identified four adaptation strategies: hybrid varieties, early maturing varieties, local varieties and income diversification; and the MVP model is an advantage as it is used to tackle the set of recursive, simultaneous decision-making processes as a system (Greene 2012). That is, since the decision may be sequential, we cannot employ single-equation model on each and a MVP approach becomes a better option as it allows for greater flexibility in associations between the explanatory variables and each of the outcome variables (i.e. adaptation strategy options). Also, it enables us to explore whether there are correlations between the unobservable characteristics associated with each outcome through the off-diagonal correlations such that if there are correlations across the equations, it suggests the different set of choices are best modelled together, otherwise they are independent.

Thus, a multivariate model that allows for the possible contemporaneous correlation in the decisions to adopt the four-climate change adaptation and/or risk management strategies that have been used by farmers was modeled following Greene (2012) as:

$$
y_{i m}=\beta_{m}^{\prime} X_{i m}+\varepsilon_{i m}, \mathrm{i}=1, \ldots, \mathrm{n} ; \mathrm{m}=1, \ldots, \mathrm{M},
$$

${ }^{1}$ Kebele is local name representing lower administrative unit after district 
where, $y_{\text {im }}(i=1, \ldots, N$ observations and $m=1, \ldots, M$ equations $)$ represent farmers' strategies of adaptation and/or risk management to climate change indicated above; $X_{i m}$ is avector of observed variables that affect the decision for adaptation and/or risk management strategies, $\beta_{m}^{\prime}$ is a $1 \mathrm{x} k$ vector of parameters to be estimated and $\varepsilon_{i m}$ is the unobserved error term distributed as multivariate normal, each with mean zero and covariance matrix $R$ such that $\left[\varepsilon_{i 1}, \ldots, \varepsilon_{i M} \sim \mathrm{N}_{M}(0, \mathrm{R})\right]$

Each $y_{i}$ is a binary variable (the dependent variable) and the above-mentioned equation is a system of $\mathrm{m}$ equations which, in our case, can be given by:

$$
\left\{\begin{array}{l}
y_{1}^{*}=\alpha_{1}+\beta_{1} X+\varepsilon_{1} \\
y_{2}^{*}=\alpha_{2}+\beta_{2} X+\varepsilon_{2} \\
y_{3}^{*}=\alpha_{3}+\beta_{3} X+\varepsilon_{3} \\
y_{4}^{*}=\alpha_{4}+\beta_{4} X+\varepsilon_{4}
\end{array}\right.
$$

With $y_{1}^{*}, y_{2}^{*}, y_{3}^{*}, y_{4}^{*}$ a set of four latent variables underlying the decision for choosing each of the climate change adaptation and/or risk management strategies such that

$$
y_{m}=\left\{\begin{array}{l}
1 \text { if } y_{m}^{*}>0 \\
0 \text { otherwise }
\end{array}, m=1 \ldots, \mathrm{M}(=4)\right.
$$

\section{Results and Discussion}

\subsection{Land allocation pattern of smallholder farmers}

In the study area, cereal crop production is dominant considering that the studied farm households allocate, on average, 2.57 ha $(92.4 \%)$ of the landholding to cereals. The farmers produce crops on two to five plots of land which would mean diseconomies of land resulting from agricultural land fragmentation.

Table 1 depicts the allocation of land to different crops with low standard deviation all the way. Maize followed by tef and haricot beans is dominant in the study areas, in terms of both the percentage of farmers and land allocation. Other crops are also grown in smaller quantities as the area experiences mixed agriculture. All of the farmers grew maize whereas less than $30 \%$ of them grew the other crops. About $95 \%$ of the farmers grow improved varieties. Local crop varieties are also grown by many (41\%) farmers and make as big as $50 \%$ of the land area allocated to improved crops.

\subsection{Use of improved crop varieties}

Farmers produce maize, haricot beans, tef and other crops in the order of their abundance. As shown in Table 2 , a number of improved varieties of these crops have been reported by the interviewed farmers indicating diversity and intensity of production of the varieties. However, it was found out that farm households interviewed preferences rest on few (two) varieties of the three major crops. Most of the farmers grow hybrid varieties of maize, export type of haricot beans and early to late maturing white type tef. Many (40\%) farmers also produce local types of tef. Such distribution of farmers could be the effect of many factors, including productivity, market demand and access to information and the established social preferences for and demonstrated merits (better performance under specific environment) of the particular crop technology. Since some of the improved varieties have been introduced in the study area long time ago (over 30 years) and due to farmer-farmer information transfer gap there could be confusion of nomenclature of these varieties. However, it needs further assessment to establish the probable reason for using these varieties and cultivars under different intensities. Thus, phenotyping (finger printing) of these crops may be useful to verify farmers' naming of the different varieties to support results of this study. The relative significance of the long existing varieties such as $\mathrm{BH} 540$ could be an indication to guide future extension and research efforts considering the desirable characteristics of such crop types.

\subsection{Farmers' perception of the type and effects of climate change}

Analysis of farmers' perception of the impact and occurrence of climate change is typified by high temperature, short rain duration, prolonged dry spell and resurgence of new insect pests in the right order. The nature of climate change was defined in terms of rainfall amount and late onset, shortage at flowering, planting and plowing and early cessation of rainfall. The effects of climate change components were expressed as a threat to crop production (96\%), drought (decreases in amount of rainfall) $(76 \%)$, exhaustion (44\%), death of livestock $(32 \%)$ and illness of human beings $(26 \%)$ (Figure 1$)$.

\subsection{Farmer's perception of climate change}

Assessment of farmers' perception of future occurrences of very important climate change elements, using their own definitions, shows that most (over $40 \%$ ) of the farmers have the expectation that the threat/impact due to low/erratic/rainfall, pests (indirect threat) and high temperature would be low in the future and a significant proportion (over $20 \%$ ) of the farmers said that the likelihood of future trends in climatic variables would be on the increase side (Fig. 2). Some farmers said that the existing scenario of high temperature (24.3\%), pest 
infestation (14\%) and low precipitation $(8.7 \%)$ will prevail in similar manner in the future. A significant proportion of the farmers has been in a state of indecision about the future trends and impacts of climate change in terms of low/erratic rainfall $(14.5 \%)$, occurrence of pests $(12.3 \%)$ and high temperature $(12.1 \%)$. The implication of the above classification of responses of farmers would be that, despite the locational similarities, farmers' perceptions are not similar in terms of depicting future trends in climate change and may require additional study to clarify reasons.

\subsection{Farmers' evaluation of responses of crop varieties to climate change}

Results of analysis of farmers' subjective evaluation revealed the differential responses of the crop varieties to the changing climate falling in the range of least to high susceptibility (Table 3). Most of the maize hybrids, as well as tef and haricot bean varieties were rated as least and slightly susceptible by over $80 \%$ of the farmers. However local maize cultivars were rated by more than $40 \%$ of the farmers as highly susceptible to changes in the climatic change elements. Conditional on the intensity of farmers' responses it can be inferred that sensitivity of improved crop varieties varies both among the crops and among the varieties. Also, it provides indications that the improved varieties have played significant role compared to the local cultivars in the face of climate change and its effects.

\subsection{Farmers' adaptation and/or risk management mechanisms}

Analysis of farmers' climate adaptation and/or risk management mechanisms shows that sampled farmers practice a number of adaptation and/or risk management options (Table 4). Accordingly, indigenous practices involving use of local varieties and crop management practices (such as ridging) are dominant. Early maturing varieties and crop protection (use of chemicals) practices are also practiced by many (about $80 \%$ ) of the farmers. Reduced use of fertilizer and shifting to other crops are characteristics of moisture-stress environment and mainly indicate the occurrence of drought due to rainfall shortage. The use of farm credit, replanting and long maturing varieties are characteristics of small number (up to $22 \%$ ) of the farmers. Usage of indigenous farming practices could mean either the lack of access to improved practices or the relative importance of the existing practices to other practices in the study area; whereas, the practice of many adaptation and/or risk management mechanisms would signal either the diversity of climate change effects demanding the practice of different mechanisms or the lack of proven adaptation and/or risk management mechanism and hence the increased vulnerability of the farmers in the study area.

Table 5 depicts sources of agricultural information for product, market and climate related activities. Accordingly, there exist varying sources of information with varying degree of involvement across the different types of information which could be explained by the frequency distribution of user farmers. The table shows the very conspicuous range and extent of involvement of the public extension service which could be due to the closer placement and frequent contacts of development agents. However, the other sources have their particular importance in terms of the specific types of information. Mass media has been important as source of climate related information to many farmers. Farmers' cooperatives and traders have higher coverage in terms of delivering information on input and output prices.

\subsection{Econometric analysis of adaptation and/or risk management strategies}

Results in table 6 showed that the multivariate probit model is significant at $1 \%$ level (Wald test: $X^{2}(88)=$ 377.27, $p=0.000$ ) indicating the goodness-of-fit of the model to estimate the data and that the subset of coefficients of the model are jointly significant and the explanatory power of the factors included in the model is satisfactory. The likelihood ratio test (LR) of independence between the strategy choices $\left(\rho_{21}=\rho_{31}=\rho_{41}=\rho_{32}\right.$ $\left.=\rho_{42}=\rho_{43}=0\right)$ is significant at $1 \%$ level indicating the test of the null hypothesis that all the $\rho$ (rho) values are jointly equal to zero is rejected and hence the goodness-of-fit of the model. Further it shows the presence of differences in the climate adaptation and/or risk management strategy selection behavior of the farmers.

The individual rho $\left(\rho_{i j}\right)$ values indicate the degree of correlation between each pair of the dependent variables. The correlation between the choice for early maturing (i.e. maize, tef, haricot beans, and wheat) varieties and hybrid (i.e. maize) varieties $(\rho 21)$ is strongly negative and significant at $1 \%$ level indicating competitive relationship betweenthe two choices. This explains that, farmers used early maturing varieties as substitutes for hybrid varieties in their flexible choice of the adaptation responses. On the other hand, the correlation between the choice for income or livelihood diversification (off-farm activities and credit) and hybrid varieties $(\rho 41)$ is positive and statistically significant at $1 \%$ level, indicating the complementary uses of the two choices. Also, the correlation between the choice for income diversification and local varieties $(\rho 43)$ is positive and statistically significant at $10 \%$ level indicating the marginal complementary uses of the two choices.

The predicted marginal success probability that farmers in the study area chose hybrids, early maturing varieties, local varieties, and income diversification strategies, in the face of climate change, was $76.2 \%, 40.5 \%$, $38.8 \%$ and $66.2 \%$ respectively. The joint probability of success of the four adaptation and/or risk management 
responses was $9.9 \%$, signaling the unlikelihood of all of the adaptation and/or risk management strategies to be chosen by the farmers in a simultaneous way; thus, implying farmers situation (socio-economic and technical merit) specific and differential preferences for the available options.

Results of the multivariate econometric model further show that farmers' decisions for adapting the overriding perceived climate change adaptation and/or risk management strategies are influenced by different sets of farmer and non-farmer specific factors (Table 6). Table 6 reveals that not a single variable cut across all of the adaptation and/or risk management strategies.

The regression results indicate that education, experience with improved seeds and extension contact have positive influence on the choice of early maturing varieties implying that these factors improve the cognitive and decision-making capacity of farmers to evaluate the potential benefit of a particular strategy (Hassan and Nhemachena, 2008; Dolisca et al., 2006; Nyangena, 2007; Anley et al., 2007). Livestock ownership has positive impact on income diversification strategy in that farmers who have livestock tend to sale their livestock and generate means of livelihood as a strategy for adaptation and/or risk management (Abrham et al., 2017, Negash, 2011).

Productivity of haricot beans has positive impact on the choice of early maturing varieties and income diversification since haricot beans are short maturing and have concurrent benefit of giving better yield (Tasew,2013) and generating cash income in times of climate change evens (Katungi, et al. 2010).Also the productivity of improved wheat has contribution for income diversification strategy and farmers who produce wheat tend to generate income from the sale of wheat taking the advantage that wheat has relatively shorter growing period and the yield is comparably better.

Land allocation to improved varieties has dual role of promoting use of hybrid varieties and limiting the use of local varieties due to the comparative advantage of hybrid varieties over the local ones in terms of higher yield and escaping the vagaries of climate change by the virtue of their short maturing nature. The fact that larger area under improved varieties can better withstand adverse climatic events due to the relative gain in better output (Di Falco et al. 2010; Assafu, et. al. 2016). The number of plots operated has positive influence on use of hybrid (maize) varieties since increase in the number of plots is an indication of vulnerability and risk diversification.

Manure has positive effect on the choice of maize hybrids and income diversification strategies (Di Falco et al. 2010). Renting out land has a positive impact on the choice of early maturing varieties whereas it has a constraining impact on local varieties. The fact that renting out of land is one of the factors positively associated with the coping responses of farmers to climate change is also consistent with studies by Abidl et al. (2015) and Gebregziabher and Holden (2011). Occurrence of early cessation of rainfall counteracts the choice of income diversification as there are limited opportunities (such as farm credit, off-farm employment) to diversify income as a means of livelihood whereas the perceived variability in rainfall pattern induces it.

Farmers at Shalla and Dugda districts share the characteristics of hybrid varieties and income diversification strategies respectively, whereas farmers at Shalla district are less likely to choose early maturing varieties compared to farmers living in their counterpart districts. Accordingly, the use of hybrid varieties is positively associated with use of manure, number of plots and proportion of land allocated to improved crops and these are the characteristics of farmers of Shalla district, compared to farmers in the other districts. The choice of early maturing varieties as adaptation response strategy is strongly governed by education level of the household head, experience with improved varieties, extension visits and haricot bean productivity gains. The choice is challenged at large by lack of adequate farming experience, and the practice of land renting. Farmers living in Dugda and Adamitulu districts are marginally characterized by use of early maturing variety option compared to those of Shalla district. Farmers who chose to use local varieties as an adaptation response strategy are those who rent out land and those who allocate less land to the production of improved crops. These may be classified as generally resource poor (could be risk averse) farmers existing in any one of the districts. The decision to choose income diversification practices, like use of farm credit and off-farm income, depends on wheat and haricot bean production, use of manure, livestock ownership and different forms of rainfall pattern. Farmers of this category generally belong to Dugda district compared to the other districts.

However, considering the categories of the different factors depicted in Table 6, we may further outline that the use of hybrid varieties is influenced by technology (productivity merits), field management and environmental characteristics. Use of improved varieties is influenced by socioeconomic, technology, field management, extension and environmental characteristics. The use of local varieties is influenced by technology and field management practices. Income diversification is influenced by economic, technology, field management and environmental characteristics. Thus, technology and field management practices are the most important factors that cut across the different adaptation response strategies.

\section{Conclusions}

This study addresses the role of agricultural technologies and the strategic decisions that farmers make in response to changes in climate. Particularly, it focuses on the status of improved agricultural technologies in the 
choice of adaptation and/or risk management mechanisms of farm households to climate change in the central rift valley of Ethiopia where moisture-stress is prevalent. It would thus provide insights in to knowledge based policy action in promoting agricultural development in the face of changing climatic scenarios. This paper tries to explain the scenario of adaptation and/or risk management to climate change via smallholder farmers' choice of strategies.

Results of descriptive analysis depict that high temperature, short rain and pests have been the most important direct and indirect phenomena of climate change causing loss of crop production, exhaustion and illness. Significant proportion of the farmers also perceived that these forces would continue in the future too. Rainfall has been the most important factor which in the face of climate change has been defined by the farmers as late onset, low at land preparation, at planting and, at vegetative stages and early cessation. Such a pattern would be better interpreted as a sign of intermittently high dry-spell.

Improved crop varieties such as maize, tef, and haricot beans are grown by many farmers, though local tef still has significant share in most of the districts. According to farmers, the improved varieties performed from less to higher susceptibility to climate change. The fact that some of the improved varieties performed better than the local ones would indicate the vital role of the technologies hence the significant pace in terms of combating the threat of climate change on crop production through improved crop technologies. In spite of this, in their struggle against climate change, the farmers used a variety of adaptation and/or risk management mechanisms implying lack of single and effective mechanism. The strategies farmers followed also vary in terms of their intensity of use. Considering the different level of engagement of the different agents in supplying agricultural information, while strengthening the success in the already established sources, expanding the coverage of these and other agents in terms of the kind of information provided and reaching the regularly unreached farmers would be important.

Results of the multivariate probit analysis imply that farmers' strategies are different and are governed by different set of enabling and constraining factors. These factors could be summarized as farmer-specific (experience, education, resource endowment), technology specific (choice crops, soil amendments), field management (resource employment), and environment specific (extension information, rainfall pattern, location) The implication would be that socioeconomic and environmental factors that are influencing the technology environment should be identified and become an integral part of any evidence-based policy option. Furthermore, farmers in the moisture-stress areas do not seem to have one single effective strategy and the nature of the strategies is both in-built and anticipatory. Therefore, it is recommended that successful strategies be evaluated and promoted from among the existing ones without compromising for new or better ones in the context of farmers' circumstances (i.e. considering the different locations). Also, priority given to technology and field management practices are the most important factors that cut across the different adaptation and/or risk management options. The role of improved technologies has been vital. However, we may conclude that the performance and availability of improved crop technologies alone is not a sufficient condition for leveling the impact of climate change.

Thus, for successful effect, policy actions ought to address the realities on the ground in designing appropriate option with better understanding of the most important constraints and opportunities that could influence farmers' choice of the different strategies and informed decision-making ability in the face of climate change.

\section{References}

Abid M., Scheffran J., Schneider, U.A. \& Ashfaq, M. (2015). Farmers' perceptions of and adaptation and/or risk management strategies to climate change and their determinants: the case of Punjab province, Pakistan. Earth Syst. Dynam., 6, 225-243, 2015.

Abrham, B., Recha, J.W., Teshale W., \& Morton, J. F. (2017). Smallholder farmers' adaptation and/or risk management to climate change and determinants of their adaptation and/or risk management decisions in the Central Rift Valley of Ethiopia. Agriculture \& Food Security 20176:24

Anley, Y., Bogale, A. \& Haile-Gabriel, A. (2007). Adoption decision and use intensity of soil and water conservation measures by smallholder subsistence farmers in Dedo district, Western Ethiopia. Land Degradation and Development 18, 289-302

Apata, T.G., Samuel, K.D., \& Adeola, A.O. (2009). Analysis of Climate Change Perception and Adaptation and/or risk management among Arable Food Crop Farmers in South Western Nigeria, Federal Department of Agricultural Economics and Extension Services, University of Technology, Ondo State, Nigeria.

Alvarez, R. M., \& Nagar, J. (2000). "A New Approach for Modelling Strategic Voting in Multiparty Elections." British Journal of Political Science. 30:57-75

Asafu-Adajaye J., Thilak M. \& Chilot Y. (2016). Strategies for managing climate risk: a case study of smallholder farmers in Ethiopia. Journal of Agricultural Economics and Rural Development Vol. 3(2), pp. 091-104, July, 2016. ISSN: 2167-0477 
Brohan, P., Kennedy J., Harris I., Tett S. F. B. \& Jones P. D. (2006). Uncertainty estimates in regional and global observed temperature changes: A new data set from 1850. J. Geophys. Res.

CorethaKomba \& Edwin Muchapondwa. (2015). Adaptation to Climate Change by Smallholder Farmers in Tanzania. Discussion Paper Series. Environment for Development, EfD DP 15-12, pp 7-9, June 2015.http://efd-dp-15-12.pdf

Crosson, P. (1983). A schematic view of resources, technology and environment in agricultural development. Agriculture, Ecosystems and Environment, 9: 339-357.

Dercon, S. (2005). Risk, Poverty and Vulnerability in Africa. Journal of African Economies, 14(4): 483-488.

Dercon, S., Hoddinott, J. \& Woldehanna, T. (2005). Vulnerability and shocks in 15 Ethiopian villages, 19992004. Journal of African Economies, 14 (4): 559-585.

Deressa, T. T., Hassan, R. M. \& Ringler, C. (2011). Perception of and adaptation and/or risk management to climate change by farmers in the Nile basin of Ethiopia. Journal of Agricultural Science, 149, 23-31. http://dx.doi.org/10.1017/S0021859610000687.

Di Falco, Marcella Veronesi and Mahmud Yesuf. (2010). Does adaptation and/or risk management to climate change provide food security? A micro-perspective from Ethiopia Salvatore. Centre for Climate Change Economics and Policy. Working Paper No. 22.

Dolisca, F., Carter, RD., McDaniel, JM., Shannon, DA. \& Jolly, CM. (2006). Factors influencing farmers' participation in forestry management programs: A case study from Haiti. Forest Ecology and Management 236, 324-31.

Gebregziabher, G. \& Holden, S. T. (2011). Distress Rentals and the Land Rental Market as a Safety Net: Evidence from Tigray, Ethiopia. Agricultural Economics 42, 45-60

Greene, W.H., 2012. Econometric analysis. (7 $7^{\text {th }}$ ed.). pp752-3. ISBN 0-13-139538-6.

Hassan, R., \& Nhemachena, C. (2008). Determinants of African farmers' strategies for adapting to climate change: Multinomial choice analysis. The African Journal of Agricultural and Resource Economics, 2(1).

Jagtap, S. (2007). Managing vulnerability to extreme weather and climate events: Implications for agriculture and food security in Africa. Proceedings of the International Conference on Climate Change and Economic Sustainability held at Nnamdi Azikiwe University, Enugu, Nigeria. 12-14 June 2007.

Jansen, H., Hengsdijk, H., Legesse, D., Ayenew, T., Hellegers, P. \& Spliethoff, P., (2007). Land and water resources assessment in the Ethiopian Central Rift Valley Alterra Report 1587. Wageningen, the Netherlands.

Kassie, B.T., Rotter, R.P., Hengsdijk, H., Asseng, S., Kahiluoto, H. \& Van Ittersum, M. K. (2013). Climate variability and change in the Central Rift Valley of Ethiopia: challenges for rain-fed crop production. Climate Change and Agriculture Research paper. Journal of Agricultural Science. Pp:1-17. Cambridge University Press

Kassie, B.T., Van Ittersum, M. K., Hengsdijk, H., Asseng, S., Wolf, J. \& Rotter, R.P. (2014). Climate-induced yield variability and yield gaps of maize (Zea mays L.) in the Central Rift Valley of Ethiopia. ELSEVIER. Field Crops Research 160 (2014):41-53

Katungi, E., Farrow, A., MutuokiT., Gebeyehu,S., Karanja, D., Alemayehu, F., Sperling, L., Beebe,S., RubyogoJ, C., \& Buruchara, R. (2010). Improving common bean productivity: An analysis of socioeconomic factors in Ethiopia and Eastern Kenya. Baseline Research Report. [Online] Available: https://www.researchgate.net/profile/Louise_Sperling2/publication/265028968 improving_common_bean_productivity_an_analysis_of_socio_conomic_factors_in_Ethiopia_and_eastern Kenya/links/543fe5870cf2be1758cfef91.pdf

McSweeney., C., New., M., Lizcano., G. \& Lu., X. (2010). The UNDP Climate Change Country Profiles Improving the Accessibility of Observed and Projected Climate Information for Studies of Climate Change in Developing Countries. Bulletin of the American Meteorological Society, 91, 157-166.

MoANR (Ministry of Agriculture and Natural Resources). (2016). Crop variety register. No. 18. Addis Ababa, Ethiopia.

Negash, M. (2011). Analysing the determinants of farmers' preference for adaptation strategies to climate change: evidence from north Shoa zone of Amhara region, Ethiopia. Doctoral dissertation.

Nwafor J. C. (2007). Global climate change: The driver of multiple causes of flood intensity in Sub-Saharan Africa. Paper presented at the International Conference on Climate Change and Economic Sustainability held at Nnamdi Azikiwe University, Enugu, Nigeria, 12-14 June 2007.

Nyangena, W. (2007). Social determinants of soil and water conservation in rural Kenya. Environment, Development and Sustainability.

Reilly, J. M. and Fuglie K.O. (1998). Future yield growth in field crops: what evidence exists? Soil and Tillage Research, 47: 275-290.

Rosenberg, N. J. (1992). Adaptation and/or risk management of agriculture to climate change. Climatic Change 21: 385-405 
UNDP, 2010. Human development report (2010). The real wealth of Nations-Pathways to human development. Houndmills. Palgrave Macmillan. [Online] Available: http://hdr.undp.org/en/media/HDR_2010_EN_ Complete_reprint.pdf

WHO (World Health Organization). (2015). Climate and health country profile-2015 Ethiopia. [Online] Available: http://apps.who.int/iris/bitstream/10665/208861/1/WHO_FWC_PHE_EPE_15.07_eng.pdf

World Bank. (2007). World development indicators. The World Bank, Washington, DC

Young, G., Valdez, E. A. \& Kohn, R. (2009). Multivariate probit models for conditional claim types. Insurance: Mathematics and Economics. 44(2): 214-228

Ziervogel, G., Nyong, A., Osman B., Conde C., Cortes S. \& Dowing T. (2006). Climate Variability and Change: Implications for Household Food Security. Assessments of Impacts and Adapt Actions to Climate Change (AIACC). Working Paper No. 20. The AI ACC Project Office, International START Secretariat, Washington DC, USA

Table 1. Land allocation by type of crop technology

\begin{tabular}{|l|c|c|c|}
\hline Category of crop varieties grown & $\begin{array}{c}\text { Households } \\
\text { growing (\%) }\end{array}$ & $\begin{array}{c}\text { Mean land area } \\
\text { (hectares) }\end{array}$ & $\begin{array}{c}\text { Standard } \\
\text { deviation }\end{array}$ \\
\hline A. Improved varieties & 95.5 & 2.22 & 0.155 \\
\hline 1. Maize & 93.0 & 1.57 & 0.084 \\
\hline 2. Tef & 18.5 & 1.51 & 0.230 \\
\hline 4. Haricot beans & 28.0 & 0.52 & 0.050 \\
\hline 3. Other crops (wheat, sorghum, millets assorted) & 29.0 & 0.84 & 0.102 \\
\hline B. Local varieties & 41.5 & 1.06 & 0.068 \\
\hline 1. Maize & 17.5 & 1.02 & 0.121 \\
\hline 2. Tef & 15.0 & 0.84 & 0.188 \\
\hline $\begin{array}{l}\text { 3. Other crops (field pea, faba beans, wheat, barley, } \\
\text { sorghum assorted) }\end{array}$ & 27.5 & 0.50 & 0.054 \\
\hline Total & 100 & 2.57 & 0.166 \\
\hline
\end{tabular}

Table 2. Distribution of most important crop varieties by percent of farmers

\begin{tabular}{|l|c|l|c|l|c|}
\hline $\begin{array}{l}\text { Maize variety use } \\
(\mathrm{N}=200)\end{array}$ & Percent & $\begin{array}{c}\text { Haricot beans } \\
(\mathrm{N}=79)\end{array}$ & Percent & $\begin{array}{c}\text { Tef varieties } \\
(\mathrm{N}=65)\end{array}$ & Percent \\
\hline Melkasa-2 and Melkasa-4 & 2.5 & Naser & 53.16 & Tsedey (DZ-Cr37) & 41.54 \\
\hline BH-540 & 57.5 & Awash 1 & 29.11 & Kuncho(DZ-Cr387) & 15.38 \\
\hline BH-543 maize & 23.0 & Mexican 142 & 6.33 & Magna (Dz-01-196) & 3.08 \\
\hline $\begin{array}{l}\text { Other hybrid } \\
\text { Pioneer/Aggar/Tabor/Shone) }\end{array}$ & 5.5 & Awash Melka & 2.53 & Local teff & 40.0 \\
\hline Raya & 4.5 & Red Wolaita & 1.27 & Total & 100 \\
\hline local maize & 7.0 & Local haricot bean & 7.59 & & \\
\hline Total & 100 & Total & 100 & & \\
\hline
\end{tabular}

Table 3. Susceptibility of major crop varieties to climate change (farmers' subjective evaluation)

\begin{tabular}{|l|l|c|c|c|c|}
\hline \multirow{2}{*}{ Crop } & Variety & \multicolumn{3}{|c|}{ Degree of susceptibility (percent of households) } \\
\cline { 2 - 6 } & & Very high & High & Slightly & least \\
\hline \multirow{5}{*}{ Maize } & BH540 $(\mathrm{N}=137)$ & 1.46 & 8.03 & 51.09 & 39.42 \\
\cline { 2 - 6 } & BH543 $(\mathrm{N}=96)$ & 2.08 & 21.88 & 53.13 & 22.92 \\
\cline { 2 - 6 } & Raya $(\mathrm{N}=20)$ & - & 10.00 & 10.0 & 80.0 \\
\cline { 2 - 6 } & Shone $(\mathrm{N}=15)$ & - & 13.33 & 60.0 & 26.67 \\
\cline { 2 - 6 } & Melkasa2/4 $(\mathrm{N}=11)$ & - & - & 27.27 & 72.73 \\
\cline { 2 - 6 } & Local maize $(\mathrm{N}=34)$ & 8.82 & 32.35 & 41.18 & 17.65 \\
\hline \multirow{5}{*}{ Tef } & Tsedey (Cross 37) $(\mathrm{N}=28)$ & 3.57 & - & 53.57 & 42.86 \\
\cline { 2 - 6 } & Kuncho (Cross 387) $(\mathrm{N}=15)$ & - & 20.00 & 33.33 & 46.67 \\
\cline { 2 - 6 } & Local $(\mathrm{N}=24)$ & 8.33 & 8.33 & 66.67 & 16.67 \\
\hline \multirow{3}{*}{ Haricot beans } & Mexican 142 $(\mathrm{N}=23)$ & 4.35 & 21.74 & 47.83 & 26.09 \\
\cline { 2 - 6 } & Nasir $(\mathrm{N}=40)$ & 7.5 & 7.5 & 37.5 & 47.5 \\
\hline
\end{tabular}


Table 4. Farmers' climate adaptation and/or risk management mechanisms

\begin{tabular}{|l|c|}
\hline Climate risk management mechanisms & $\begin{array}{c}\text { Percent of households } \\
(\mathrm{N}=200)\end{array}$ \\
\hline Indigenous practices (use of existing cultivars) & 87.0 \\
\hline Early Maturing varieties & 82.5 \\
\hline Crop protection (chemical application) & 78.0 \\
\hline Reduced use of chemical fertilizer & 53.0 \\
\hline High yielding varieties & 48.0 \\
\hline Shifting to other crops & 42.5 \\
\hline Farm credit & 22.0 \\
\hline Replanting & 13.5 \\
\hline Long maturing varieties & 12.0 \\
\hline
\end{tabular}

Table 5. Source of information of climate and market related activities (percent of farmers)

\begin{tabular}{|l|c|c|c|c|c|}
\hline $\begin{array}{l}\text { Sources } \\
\text { information }\end{array}$ & $\begin{array}{c}\text { Clima } \\
\text { te }\end{array}$ & $\begin{array}{c}\text { Prices of inputs (fertilizer, seed, } \\
\text { chemicals) }\end{array}$ & $\begin{array}{c}\text { Livestock } \\
\text { managem } \\
\text { ent (feed, } \\
\text { AI) }\end{array}$ & $\begin{array}{c}\text { Output } \\
\text { prices }\end{array}$ & $\begin{array}{c}\text { Grain quality and } \\
\text { quantity }\end{array}$ \\
\hline None & 4.5 & 2.0 & 24.0 & 2,0 & 3.5 \\
\hline Cooperatives & 2.5 & 53.0 & 0.5 & 25.5 & 14.5 \\
\hline Extension agents & 44.5 & 32.5 & 70.0 & 20.5 & 61.5 \\
\hline Family & - & 0.5 & 0.5 & - & - \\
\hline Mass media & 39.5 & 0.5 & - & 7.5 & 6.0 \\
\hline Fellow farmers & 5.5 & - & - & - & 1.0 \\
\hline Research & - & - & 0.5 & - & 4.5 \\
\hline Own experience & 3.5 & 2.5 & 4.5 & 7.5 & 9.0 \\
\hline Traders/buyers & - & 9.0 & - & 37.0 & 100 \\
\hline Total (\%) & 100 & 100 & 100.0 & 100 & \\
\hline
\end{tabular}

Table 6. Factors associated with strategies of adaptation and/or risk management to climate change (Analysis of farmers' perception)

\begin{tabular}{|c|c|c|c|c|c|c|c|c|}
\hline \multirow{2}{*}{ Variables } & \multicolumn{2}{|c|}{ Hybrid varieties } & \multicolumn{2}{|c|}{ Early maturing varieties } & \multicolumn{2}{|c|}{ Local varieties } & \multicolumn{2}{|c|}{ Income diversification } \\
\hline & Coefficient & R.Std. Err. & Coefficient. & R.Std. Err. & Coefficient. & R.Std .Err & Coefficient & R.Std. Err \\
\hline \multicolumn{9}{|l|}{ A. Socioeconomic characteristics } \\
\hline Sex of head & -0.276 & 0.385 & 0.561 & 0.363 & -0.198 & 0.302 & 0.318 & 0.382 \\
\hline Education & -0.017 & 0.032 & $0.081^{* *}$ & 0.034 & 0.002 & 0.031 & 0.050 & 0.037 \\
\hline Dependency ratio & -0.136 & 0.109 & -0.001 & 0.107 & 0.160 & 0.101 & 0.055 & 0.124 \\
\hline Farming experience & -0.003 & 0.012 & $-0.024^{* *}$ & 0.012 & -0.003 & 0.012 & 0.011 & 0.015 \\
\hline Experience with improved seed & 0.009 & 0.028 & $0.069^{* \cdots}$ & 0.026 & 0.028 & 0.025 & 0.018 & 0.029 \\
\hline Livestock ownership (TLU) & 0.002 & 0.017 & 0.022 & 0.016 & 0.020 & 0.015 & $0.067^{* *}$ & 0.023 \\
\hline Land allocated to improved crops (\%) & $0.014^{\cdots *}$ & 0.005 & -0.005 & 0.005 & $-0.015^{* *}$ & 0.005 & -0.001 & 0.006 \\
\hline \multicolumn{9}{|l|}{ B. Technology } \\
\hline DAP and Urea (kg) & -0.002 & 0.001 & -0.001 & 0.001 & 0.0003 & 0.001 & 0.002 & 0.002 \\
\hline Productivity of improved maize & -0.001 & 0.036 & -0.035 & 0.035 & -0.018 & 0.033 & -0.035 & 0.041 \\
\hline Productivity of haricot beans & 0.031 & 0.055 & $0.168^{* \cdots}$ & 0.046 & -0.037 & 0.047 & $0.126^{\circ *}$ & 0.057 \\
\hline Productivity of improved tef & 0.219 & 0.195 & 0.233 & 0.167 & -0.192 & 0.206 & -0.033 & 0.243 \\
\hline Productivity of improved wheat & 0.044 & 0.065 & 0.035 & 0.064 & 0.103 & 0.065 & $0.179^{*}$ & 0.098 \\
\hline \multicolumn{9}{|l|}{ C. Field management } \\
\hline Number of plots operated & $0.131^{\circ}$ & 0.072 & -0.035 & 0.079 & 0.011 & 0.068 & -0.029 & 0.081 \\
\hline Land renting out (1=yes) & -0.211 & 0.485 & $-0.864^{* *}$ & 0.395 & $0.945^{* *}$ & 0.470 & 0.903 & 0.579 \\
\hline Manure use (1=yes) & $0.469^{* *}$ & 0.231 & 0.202 & 0.223 & -0.370 & 0.234 & $0.681^{*+*}$ & 0.255 \\
\hline \multicolumn{9}{|l|}{ D. Environment } \\
\hline Distance to seed market & 0.003 & 0.002 & -0.002 & 0.003 & -0.002 & 0.002 & -0.001 & 0.002 \\
\hline Extension visits & -0.110 & 0.215 & $0.640^{* * *}$ & 0.208 & 0.001 & 0.203 & -0.067 & 0.230 \\
\hline Late onset of rain (1=yes) & 0.056 & 0.438 & -0.662 & 0.505 & 0.622 & 0.567 & -0.188 & 0.429 \\
\hline Early cessation (1=yes) & 0.337 & 0.866 & -0.757 & 0.834 & -0.211 & 0.876 & $-2.463^{* * *}$ & 0.942 \\
\hline Interaction of rainfall pattern & -0.424 & 0.902 & 1.328 & 0.881 & 0.927 & 0.934 & $2.695^{+* *}$ & 0.981 \\
\hline Shalla district (1=yes) & $0.701^{* *}$ & 0.288 & $-0.466^{*}$ & 0.282 & 0.063 & 0.259 & 0.337 & 0.274 \\
\hline Dugda district (1=yes) & -0.484 & 0.399 & -0.151 & 0.393 & 0.447 & 0.418 & $1.566^{* * *}$ & 0.527 \\
\hline Constant & -0.654 & 0.805 & -0.546 & 0.944 & -0.238 & 0.944 & -1.636 & 1.036 \\
\hline \multirow{3}{*}{ Correlation coefficients } & $\rho_{21}=-0.629^{* * *}$ & & & & & & & \\
\hline & $\rho_{31=}-0.176$ & & $\rho_{32}=0.213$ & & & & & \\
\hline & $\rho_{41}=0.345^{* * *}$ & & $\rho_{42}=0.060$ & & $\rho_{43}=0.248^{*}$ & & & \\
\hline Number of obs. & 200 & & & & & & & \\
\hline Wald $\mathrm{Chi}^{2}(88)$ & 377.27 & & & & & & & \\
\hline Log pseudo likelihood & -371.411 & & & & & & & \\
\hline Prob $>\mathrm{chi}^{2}$ & 0.000 & & & & & & & \\
\hline $\mathrm{Chi}^{2}(6)$ & $36.348^{\circ * *}$ & & & & & & & \\
\hline
\end{tabular}

$*{ }^{* *},{ }^{* * *}$ represent statistical significance of factors at 10,5 , and $1 \%$ levels respectively 


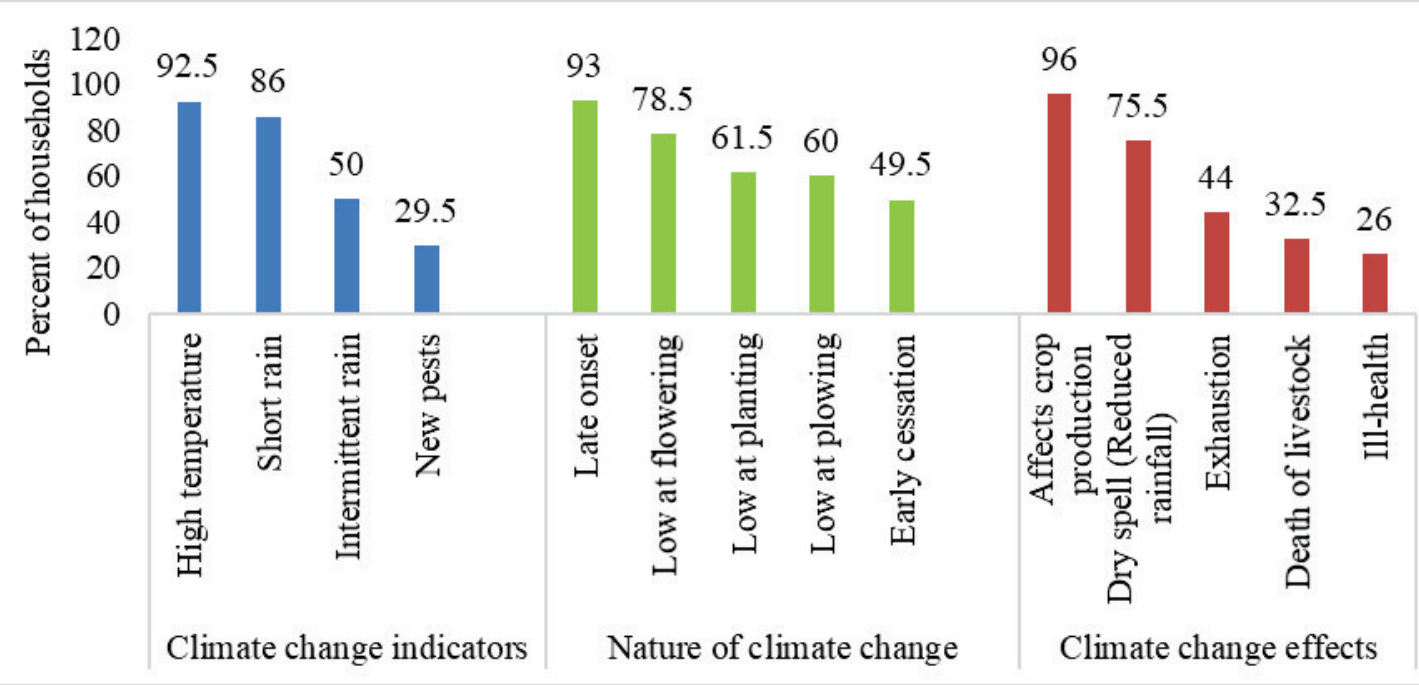

Figure 1 Perceptions of farmers on type and effects of climate change

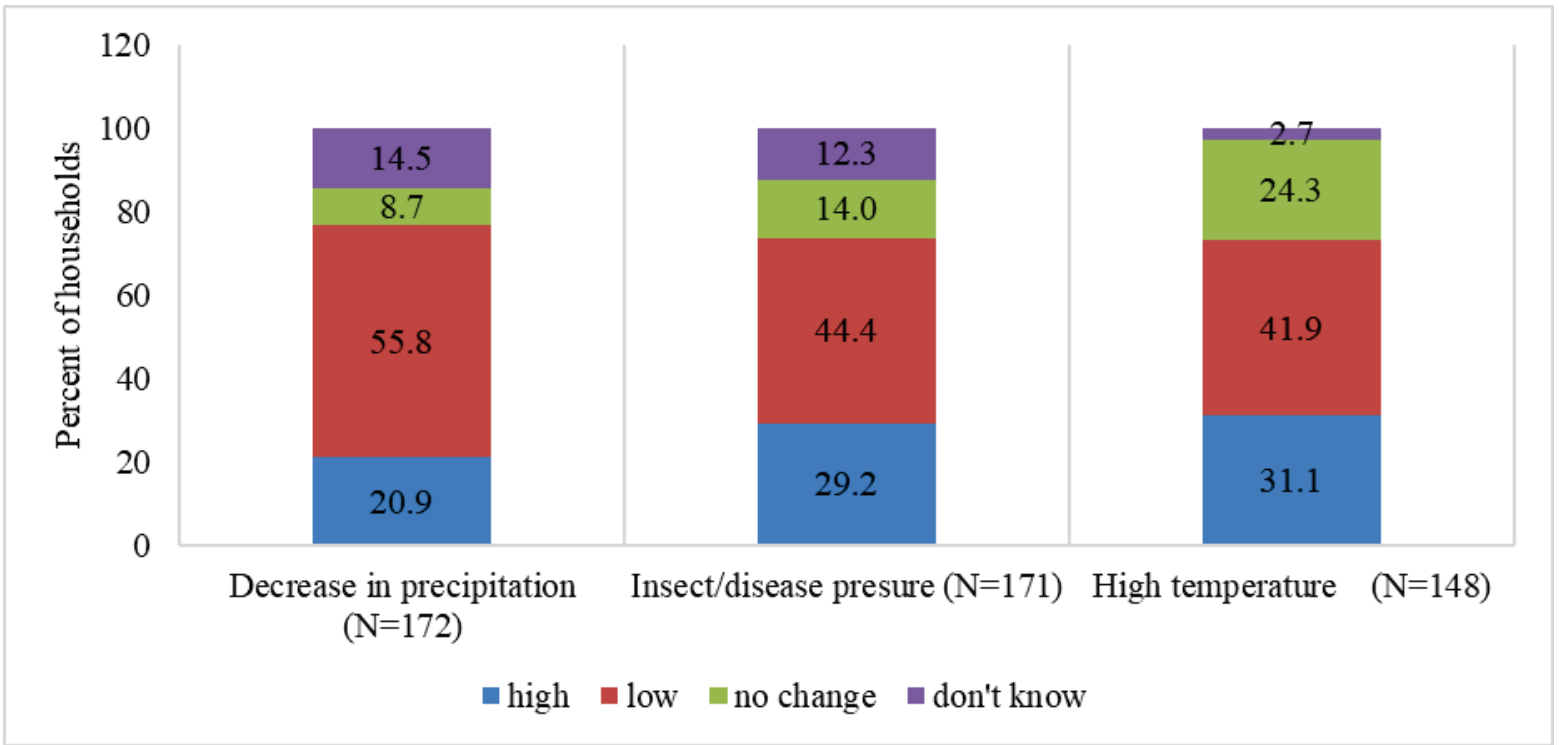

Figure 2. Farmers' perception of future occurrences of climate/impact elements 